\title{
Pentose Phosphate-dependent Fixation of Formaldehyde by Methanol-grown Hansenula polymorpha and Candida boidinii
}

\author{
By MARY L. O'CONNOR† AND J. R. QUAYLE* \\ Department of Microbiology, The University, Sheffield S10 2TN
}

(Received 3 April 1980)

\begin{abstract}
A method has been developed for the continuous spectrophotometric assay of dihydroxyacetone synthase present in methanol-grown yeasts. This enzyme catalyses the condensation of formaldehyde with a pentose phosphate (most probably xylulose 5-phosphate) to give dihydroxyacetone and glyceraldehyde 3-phosphate. The assay is based on the NADHand ATP-linked formation of L-glycerol 3-phosphate from dihydroxyacetone via the added coupling enzymes glycerol kinase and glycerol-3-phosphate dehydrogenase, and the reaction was followed by the decrease in absorbance at $340 \mathrm{~nm}$. Using this assay, the $\mathrm{pH}$ optimum of the dihydroxyacetone synthase was shown to be $7 \cdot 4$ to $7 \cdot 6$. The enzyme, which catalyses a transketolase-like reaction, is a separate enzyme from the classical transketolase because their specific activities varied independently in Candida boidinii and Hansenula polymorpha grown on different substrates and the two enzyme activities could be separated by ionexchange chromatography.
\end{abstract}

\section{INTRODUCTION}

Recent studies (van Dijken et al., 1978; Babel \& Loffhagen, 1979; O’Connor \& Quayle, 1979; Kato et al., 1979; Waites \& Quayle, 1980; Lindley et al., 1980) have shown that a novel pentose phosphate cycle of formaldehyde fixation operates in methanol-utilizing yeasts. One of the key steps of this cycle is the condensation of xylulose 5-phosphate with formaldehyde to give dihydroxyacetone (DHA) and glyceraldehyde 3-phosphate (Kato et al., 1979; Waites \& Quayle, 1980). The enzyme(s) which is presumably responsible for catalysing this reaction has been given the trivial name 'DHA synthase' and it seems likely that it is a type of transketolase in which formaldehyde acts as the aldehyde acceptor for transfer of a glycolaldehyde fragment from carbon atoms 1 and 2 of the xylulose 5-phosphate. It may be recalled that Dickens \& Williamson (1958) discovered that transketolase from Saccharomyces cerevisiae catalysed a slow condensation of hydroxypyruvate with formaldehyde to give DHA and carbon dioxide.

Now that the existence of the DHA synthase reaction in extracts of methanol-grown yeasts has clearly been established it is of interest to determine the nature of the enzyme(s) responsible and to establish its identity or otherwise with the transketolase present in yeasts grown on substrates other than methanol. The work described in the present paper is directed to this problem in regard to the methylotrophic yeasts, Candida boidinii and Hansenula polymorpha.

$\dagger$ Present address: Department of Microbiology, University of Washington SC-42, Seattle, Washington 98195, U.S.A. 


\section{METHODS}

Abbreviations. DHA, dihydroxyacetone; DHAP, dihydroxyacetone 3-phosphate; GAP, glyceraldehyde 3-phosphate; XuMP, xylulose 5-phosphate.

Organisms. Hansenula polymorpha CBS 4732 and Candida boidinii CBS 5777.

Media and grow'th conditions. Organisms were grown in shake flasks at $37^{\circ} \mathrm{C}$ (for $\mathrm{H}$. polymorpha) or $30^{\circ} \mathrm{C}$ (for $C$. boidinii) in the mineral salts medium used by van Dijken et al. (1976). Filter-sterilized methanol $(0.5 \%$ w/v), ethanol $(0.2 \%, \mathrm{w} / \mathrm{v})$ or dihydroxyacetone $(0.1 \%, \mathrm{w} / \mathrm{v})$ and autoclaved glucose or glycerol $(0.2 \%, \mathrm{w} / \mathrm{v})$ were used as carbon and energy sources. For all enzyme studies, cultures were harvested in late-exponential phase.

Preparation of extracts. Cell-free extracts were prepared by ultrasonication (MSE model $150 \mathrm{~W}$ ) for $7 \times 1 \mathrm{~min}\left(H\right.$. polymorpha) or $5 \times 1 \mathrm{~min}$ (C. boidinii) at $1 \mathrm{~min}$ intervals in 4 vol. $20 \mathrm{~mm}-\mathrm{KH}_{2} \mathrm{PO}_{4} / \mathrm{NaOH}$ buffer pH $7 \cdot 1$ (for enzyme assays) or $20 \mathrm{~mm}$-glycylglycine buffer $\mathrm{pH} 7.6$ containing $5 \mathrm{mM}-\mathrm{MgCl}_{2}$ (for purification of C. boidinii DHA synthase). The supernatant obtained after centrifugation at $38000 \mathrm{~g}$ for $20 \mathrm{~min}$ was used for all enzyme studies.

Enzyme assays. All assays were carried out in $1 \mathrm{ml}$ total volume at $37^{\circ} \mathrm{C}\left(\mathrm{H}\right.$. polymorpha) or $30^{\circ} \mathrm{C}(\mathrm{C}$. boidinii) using a Pye Unicam SP1800 double-beam recording spectrophotometer.

Transketolase (EC 2.2.1.1) was assayed as described by de la Haba et al. (1955) using a commercial mixture of triosephosphate isomerase and glycerol-3-phosphate dehydrogenase (Boehringer).

Dihydroxyacetone synthase was assayed by two methods. (1) Based on triose phosphate formation. The complete reaction mixture contained: glycylglycine buffer $\mathrm{pH} 7.6,50 \mathrm{~mm} ; \mathrm{MgCl}_{2}, 2 \mathrm{~mm}$; $\mathrm{NADH}, 0.15 \mathrm{~mm}$; thiamin pyrophosphate, $0.005 \%(\mathrm{w} / \mathrm{v})$; triosephosphate isomerase (EC 5.3.1.1), 6 units; glycerol-3phosphate dehydrogenase (EC 1.1.1.8) (from rabbit muscle), 0.5 unit. After incubation of cell-free extracts with the above mixture for 5 min to assess NADH oxidase activity and to allow initial rates to level off, XUMP was added to a final concentration of $2.5 \mathrm{~mm}$ and incubation was continued for an additional $5 \mathrm{~min}$ to allow initial high rates to level off. The synthase reaction was then started by the addition of formaldehyde to a final concentration of $1 \mathrm{~mm}$. Since crude extracts exhibited a XuMP-independent formaldehyde reduction, all assays were also performed with the opposite order of addition of formaldehyde and XuMP, i.e. formaldehyde first, followed by XuMP.

(2) Based on dihydroxyacetone formation. The complete reaction mixture contained: glycylglycine buffer pH 7.6, $50 \mathrm{~mm} ; \mathrm{MgCl}_{2}, 2 \mathrm{~mm}$; NADH, $0.15 \mathrm{~mm}$; thiamin pyrophosphate, $0.005 \%$ (w/v); ATP, $1 \mathrm{~mm}$; glycerol kinase (EC 2.7.1.30) (from Candida mycoderma), 0.4 unit; glycerol-3-phosphate dehydrogenase, 0.4 unit. The assay was carried out as for assay 1 , above.

Partial purification of $D H A$ synthase and transketolase from $H$. polymorpha and C. boidinii. Step 1: ammonium sulphate treatment. The crude extracts were taken to $50 \%$ saturation with $\left(\mathrm{NH}_{4}\right)_{2} \mathrm{SO}_{4}$ by the slow addition of solid $\left(\mathrm{NH}_{4}\right)_{2} \mathrm{SO}_{4}$ at $0^{\circ} \mathrm{C}$. The table of Dawson et al. (1969) was used to compute the amount required. After equilibration at $0^{\circ} \mathrm{C}$ for $1 \mathrm{~h}$, the mixture was centrifuged $\left(38000 \mathrm{~g}, 10 \mathrm{~min}, 0^{\circ} \mathrm{C}\right)$ and the supernatant was made up to $70 \%$ saturation with $\left(\mathrm{NH}_{4}\right)_{2} \mathrm{SO}_{4}$. This mixture was equilibrated and centrifuged as above and the fraction precipitating between 50 and $70 \%$ saturation was redissolved in 20 mM-glycylglycine buffer $\mathrm{pH} 7.6$ containing $5 \mathrm{mM}-\mathrm{MgCl}_{2}$ and used for DEAE-cellulose chromatography.

Step 2: DEAE-cellulose chromatography. The fractions obtained from $\left(\mathrm{NH}_{4}\right)_{2} \mathrm{SO}_{4}$ treatment were desalted on a Sephadex G-25 column and applied to columns $(1.5 \times 4 \mathrm{~cm})$ of DEAE-cellulose (Whatman DE52) previously equilibrated with $20 \mathrm{mM}$-glycylglycine buffer pH 7.6 containing $5 \mathrm{mM}-\mathrm{MgCl}_{2}$ and $20 \%(\mathrm{w} / \mathrm{v}) \mathrm{gly}$ cerol. The proteins were then eluted with a linear $\mathrm{NaCl}$ gradient $(0$ to $0.3 \mathrm{M}$ made up in $400 \mathrm{ml}$ of the column buffer) and $5 \mathrm{ml}$ fractions were collected.

Analytical methods and chemicals. Protein was estimated by the Lowry method using bovine serum albumin as standard. Biochemicals and enzymes were obtained from Boehringer except for the following: DLglyceraldehyde and DHA from BDH; ribose 5-phosphate, ribulose 5-phosphate and XuMP from Sigma. Formaldehyde was prepared from an aqueous suspension of paraformaldehyde by heating in a closed vessel overnight.

\section{RESULTS}

Detection and assay of dihydroxyacetone synthase

The detection and assay of the DHA synthase reaction:

$$
\mathrm{HCHO}+\mathrm{XuMP} \longrightarrow \mathrm{DHA}+\mathrm{GAP}
$$

can be approached in several ways. The disappearance of formaldehyde or appearance of 
DHA can be followed colorimetrically (Kato et al., 1979; Waites \& Quayle, 1980), but both methods of estimation lead to discontinuous enzyme assays which are inconvenient for multiple use. Use of continuous spectrophotometric assays of product formation catalysed by crude extracts of these methanol-grown yeasts is fraught with difficulties for the following reasons. Firstly, crude extracts are rich in transketolase and pentose phosphate epimerases and isomerases and these combined activities result in the formation of GAP which is independent of formaldehyde. Secondly, crude extracts contain high levels of NADH-linked formaldehyde and DHA reductase activities which are independent of XuMP. The formaldehyde reductase activity may possibly be due to the activity of ethanol dehydrogenase, and the physiological role of the DHA reductase is probably that of a glycerol dehydrogenase. Hence any coupled assay which involves dehydrogenation of reduced nicotinamide nucleotides can be expected to involve high blank rates.

An attempt was made to detect formaldehyde-and XuMP-dependent formation of GAP by coupling its formation to the action of triosephosphate isomerase and glycerol-3-phosphate dehydrogenase (assay 1 in Methods).

$$
\begin{aligned}
\text { GAP } & \rightleftharpoons \text { DHAP } \\
\text { DHAP }+\mathrm{NADH} & \longrightarrow \text { L-Glycerol 3-phosphate + NAD }
\end{aligned}
$$

High blank rates were observed and no reproducible and stable rate of NADH oxidation which was dependent on the simultaneous presence of formaldehyde and XuMP was detected.

Positive and more reproducible results were, however, obtained by measuring DHA formation by assay 2 (see Methods). This assay involved coupling DHA formation to the action of the glycerol kinase of $C$. mycoderma which catalyses the phosphorylation of not only glycerol but also DHA (Hers, 1962; Gancedo et al., 1968).

$$
\mathrm{DHA}+\mathrm{ATP} \longrightarrow \mathrm{DHAP}+\mathrm{ADP}
$$

The DHAP formation was then followed by NADH oxidation via reaction (3). Under these conditions, in crude extracts of both yeasts, the rates of NADH oxidation observed in the presence of formaldehyde or XuMP singly were increased approximately twofold (at least) when both substrates were present together (Fig. 1). This activity, dependent on the simultaneous presence of both substrates, was also dependent on the presence of ATP and the coupling enzymes glycerol-3-phosphate dehydrogenase and glycerol kinase. We therefore ascribe this activity to the presence of enzyme(s) catalysing reaction (1), i.e. 'DHA synthase'.

The calculation of DHA synthase activity from the recorder traces may best be illustrated by an actual example worked out from Fig. $1(a, b)$. From Fig. $1(a)$ the final steady rates of change of $A_{340} \mathrm{~min}^{-1}$ were: initial, 0.025 ; after addition of XuMP, 0.030; after addition of formaldehyde, $0 \cdot 070$. Thus, the increment of rate decrease of $A_{340}$ consequent upon addition of formaldehyde was $0.040 \mathrm{~min}^{-1}$. This rate, however, contained within it a contribution from NADH-linked formaldehyde reductase activity, which was corrected for by reference to Fig. 1(b). This latter measurement gave final steady rates of change of $A_{340} \mathrm{~min}^{-1}$ as follows: initial, 0.025; after addition of formaldehyde, 0.035; after addition of XuMP, 0.06. Therefore, the rate of decrease of $A_{340} \mathrm{~min}^{-1}$ due to formaldehyde reductase activity was $0.035-0.025=0.010$. Hence, the fully corrected rate in Fig. $1(a)$ was $0.040-0.010=$ $0.030 \Delta A_{340} \min ^{-1}$. By a similar process, a fully corrected rate in Fig. $1(b)$ could be calculated, using a correction from Fig. 1 $(a)$ for the XuMP-dependent (but formaldehyde-independent) rate of change of $A_{340}$, viz. $0.030-0.025=0.005$. This then gave a fully corrected rate for Fig. $1(b)$ of $0.060-0.035-0.005=0.020 \Delta A_{340} \mathrm{~min}^{-1}$. For reasons that are not at present understood, higher activities were generally obtained when XuMP was added before formaldehyde, as in Fig. 1(a).

Using this assay, specific activities in crude extracts prepared from methanol-grown cells 


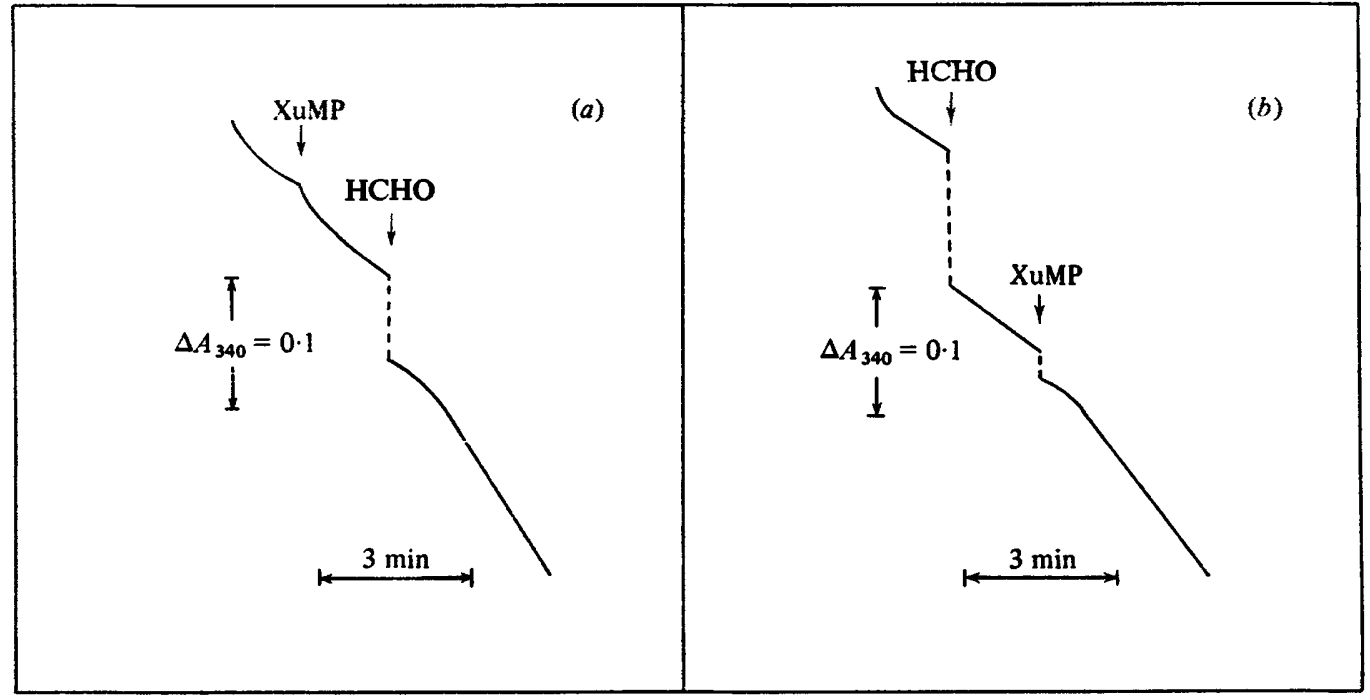

Fig. 1. Recorder tracings of the spectrophotometric assay of DHA synthase activity in crude extracts of methanol-grown $\boldsymbol{H}$. polymorpha. The assay was based on the use of glycerol kinase and glycerol-3phosphate dehydrogenase as coupling enzymes (assay 2 in Methods). The order of addition of XuMP and formaldehyde was reversed in $(b)$ relative to that in $(a)$.

Table 1. Specific activities of DHA synthase and transketolase in crude extracts of $H$. polymorpha and $C$. boidinii grown on various substrates

The assay method for DHA synthase was the continuous spectrophotometric assay as described in Fig. 1.

Specific activity $\left[\mu \mathrm{mol} \mathrm{min}^{-1}(\mathrm{mg} \text { protein })^{-1}\right]$

Growth substrate

Methanol

Dihydroxyacetone

Glycerol

Ethanol

Glucose
DHA synthase

\begin{tabular}{ccccc}
\hline \multicolumn{2}{c}{ DHA synthase } & \multicolumn{2}{c}{ Transketolase } \\
0.10 & 0.22 & $\overbrace{H . \text { polymorpha }}$ & C. boidinii \\
ND & ND & 0.23 & 0.08 \\
ND & ND & 0.20 & 0.24 \\
ND & ND & 0.17 & 0.25 \\
ND & ND & 0.14 & 0.12 \\
& & 0.29 & 0.19
\end{tabular}

ND, None detected.

proved variable in both organisms, ranging up to $0 \cdot 10$ and $0 \cdot 22 \mu \mathrm{mol}$ NADH oxidized min $^{-1}$ (mg protein) $)^{-1}$ in $H$. polymorpha and $C$. boidinii, respectively. The many interfering activities present in crude extracts render the assay quantitatively unreliable under such conditions and it is preferable in such circumstances to use the discontinuous procedure developed by Waites \& Quayle (1980). However, in later stages of enzyme purification, when interfering activities have been removed, the continuous spectrophotometric assay becomes increasingly useful.

The specific activity of DHA synthase was measured in crude extracts of $C$. boidinii and $H$. polymorpha, grown on various substrates, by direct spectrophotometric assay method 2 and compared with that of transketolase (Table 1). DHA synthase was only detected when the organisms were grown on methanol, whereas transketolase was detected after growth on all substrates tested. This suggests that the two activities are due to two different enzymes. 


\section{Table 2. Substrate specificity of DHA synthase from $H$. polymorpha and C. boidinii}

All substrates were tested by the continuous spectrophotometric assay as described in Fig. 1. Substrates were used at a final concentration of $2.5 \mathrm{~mm}$ (except for ribose 5-phosphate which was at $5 \mathrm{mM}$ ). The specific activities of the enzyme preparations with XuMP were $0.08 \mu \mathrm{mol} \mathrm{min}^{-1}(\mathrm{mg}$ protein $)^{-1}$ for $H$. polymorpha and $0.17 \mu \mathrm{mol} \mathrm{min}^{-1}$ (mg protein) ${ }^{-1}$ for $C$. boidinii. The preparations used were 50 to $70 \%$ saturation ammonium sulphate fractions, as described in Methods.

\section{Substrate}

Xylulose 5-phosphate

Ribulose 5-phosphate

Fructose 6-phosphate

Ribose 5-phosphate

Ribose 5-phosphate+ added ribose-5-phosphate isomerase+ added ribulose-5-phosphate 3-epimerase

$\begin{array}{cc}\text { H. polymorpha } & \text { Relative activity (\%) } \\ 100 & 100 \\ 50 & 79 \\ 14 & 14 \\ 0 & 0 \\ \text { NT } & \\ & 100\end{array}$

NT, This could not be tested in $H$. polymorpha preparations due to high transketolase activities.

Table 3. Partial purification of DHA synthase and transketolase from methanolgrown C. boidinii

The crude extract was prepared from $5 \mathrm{~g}$ cell paste suspended in $20 \mathrm{ml} 20 \mathrm{mM}$-glycylglycine buffer pH 7.6 containing $5 \mathrm{mM}-\mathrm{MgCl}_{2}$. DHA synthase was assayed using a mixture of ribose 5-phosphate and pentose phosphate interconverting enzymes, see Table 2 . Activities are expressed as $\mu \mathrm{mol} \mathrm{min}^{-1}$, and specific activities as $\mu \mathrm{mol} \mathrm{min}^{-1}$ (mg protein) ${ }^{-1}$.

DHA synthase

Step

Crude extract

50 to $70_{\%}^{\circ}\left(\mathrm{NH}_{4}\right)_{2} \mathrm{SO}_{4}$ fraction Sephadex G-25 chromatography DEAE-cellulose chromatography

Step

Crude extract

50 to $70 \%\left(\mathrm{NH}_{4}\right)_{2} \mathrm{SO}_{4}$ fraction

Sephadex G-25 chromatography

DEAE-cellulose chromatography

\begin{tabular}{ccccc}
$\begin{array}{c}\text { Volume } \\
(\mathrm{ml})\end{array}$ & $\begin{array}{c}\text { Total } \\
\text { activity }\end{array}$ & $\begin{array}{c}\text { Specific } \\
\text { activity }\end{array}$ & $\begin{array}{c}\text { Yield } \\
(\%)\end{array}$ & $\begin{array}{c}\text { Purifi- } \\
\text { cation }\end{array}$ \\
21 & 15.9 & 0.084 & 100 & 1 \\
2.2 & 16.7 & 0.433 & 105 & 5.2 \\
33 & 6.7 & 0.155 & 42 & 1.8 \\
11.5 & 0.8 & 0.285 & 5 & 3.4 \\
\multicolumn{5}{c}{ Transketolase } \\
\multicolumn{5}{c}{ SHA synthase } \\
Volume & Total & Specific & Yield & Purifi- \\
$(\mathrm{ml})$ & activity & activity & $(\%)$ & cation \\
21 & 15.9 & 0.084 & 100 & 1 \\
2.2 & 9.9 & 0.258 & 62 & 3.1 \\
33 & 9.3 & 0.250 & 59 & 3.0 \\
45 & 8.2 & 1.22 & 51 & 14.5
\end{tabular}

\section{Partial purification of $\mathrm{DHA}$ synthase}

The DHA synthase activity in extracts of $H$. polymorpha or $C$. boidinii could be precipitated between 50 and $70 \%$ saturation with ammonium sulphate and testing of this fraction showed that the best substrate for the reaction was XuMP (Table 2). Consistent with this was the finding that with the extract from $C$. boidinii, the activity of XuMP could be mimicked by the addition of ribose 5-phosphate only in the presence of added ribose-5-phosphate isomerase and ribulose-5-phosphate 3-epimerase. This test could not be repeated with the preparation from $\boldsymbol{H}$. polymorpha because of the higher interfering levels of transketolase which were present.

The $\mathrm{pH}$ optimum of the DHA synthase in C. boidinii was $7 \cdot 4$ to $7 \cdot 6$; the enzyme showed markedly less activity in Tris buffer than in phosphate or glycylglycine. Similar results were obtained with $H$. polymorpha. 


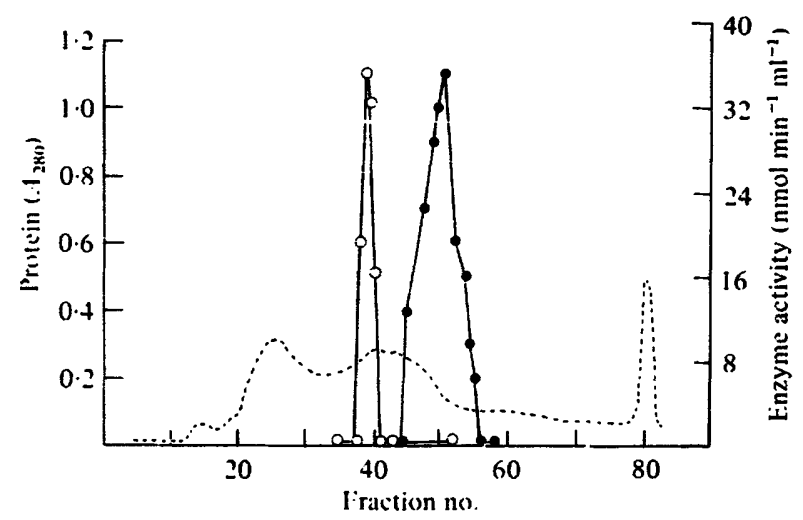

Fig. 2. Separation of DHA synthase and transketolase by chromatography on DEAE-cellulose using a linear gradient of $\mathrm{NaCl}$. Details are given in Methods. Samples $(50 \mu \mathrm{l})$ of fractions were assayed for enzyme activity [results are expressed as $\mathrm{nmol} \mathrm{min}^{-1}(\mathrm{ml} \text { sample) })^{-1}$ ]: $O$, DHA synthase;

, transketolase. Protein was monitored by measurement of absorbance at $280 \mathrm{~nm}(---)$.

Difficulties were encountered in the further purification of DHA synthase from either $H$. polymorpha or $C$. boidinii owing to the instability of the enzymes. The enzyme from $C$. boidinii was, however, more stable than that from $H$. polymorpha and was subjected to fractionation with ammonium sulphate, desalting on a column of Sephadex G-25 followed by chromatography on a column of DEAE-cellulose, using a gradient of $\mathrm{NaCl}$ (see Methods). It was found advantageous to include $20 \%$ (w/v) glycerol in the column buffer and eluting buffer as this stabilized the DHA synthase to some extent. With this procedure a partial purification of DHA synthase was effected in which the DHA synthase and transketolase activities were purified to different extents (Table 3). During the DEAE-cellulose chromatography the DHA synthase and transketolase activities clearly separated into two peaks, showing that they were indeed due to different enzymes (Fig. 2). The purified DHA synthase was very unstable at this stage, losing all activity within $12 \mathrm{~h}$ at $4^{\circ} \mathrm{C}$.

\section{DISCUSSION}

The studies described by Kato et al. (1979), Waites \& Quayle (1980) and by the present authors are together consistent with the presence of an enzyme catalysing reaction (1) in extracts of methanol-grown Kloeckera 2201, C. boidinii CBS 5777 and $\boldsymbol{H}$. polymorpha CBS 4732. Due to the many interfering activities present in crude extracts of such yeasts, the unequivocal and accurate assay of the enzyme in crude extracts can present considerable problems which have been exposed in the present paper and the previous paper by Waites \& Quayle (1980). Bearing these difficulties in mind it should be noted that the specific activities of DHA synthase recorded by three groups of authors in the three different yeasts grown on methanol fall within the range 80 to $220 \mathrm{nmol} \mathrm{min}^{-1}$ (mg protein) ${ }^{-1}$. Waites \& Quayle (1980) have estimated that a specific activity of $150 \mathrm{nmol} \mathrm{m^{-1 }}\left(\mathrm{mg}\right.$ protein) ${ }^{-1}$ for this enzyme would be sufficient to support a mean generation time on methanol of $6.4 \mathrm{~h}$ (assuming the carbon and protein contents of the cellular dry weight are each $50 \%$ and that all the carbon of the cell is incorporated via DHA).

The fact that DHA synthase is only synthesized during growth on methanol while the classical transketolase is synthesized to high levels during growth on all substrates tested indicates that the two activities are due to different enzymes. This is confirmed in the present study by the clear separation of these two activities by ion-exchange chromatography. Further study of the properties of the purified DHA synthase and detailed comparison of it with transketolase have, so far, been hampered by its apparent instability. 
We acknowledge helpful discussion with Dr J. P. van Dijken, Dr W. Harder, Dr A. J. Beardsmore and Dr M. J. Waites and we are grateful for financial support from the Leverhulme Trust (to M.L. O'C) and from the Science Research Council by way of grant no. GR/A/65966.

\section{REFERENCES}

BABEL, W. \& LoffHAGeN, N. (1979). Assimilation of methanol by yeasts, a new approach. Zeitschrift für allgemeine Mikrobiologie 19, 299-302.

Dawson, R. M. C., Ellotr, D. C., Elliott, W. H. \& JONES, K. M. (1969). Data for Biochemical Research, 2nd edn. Oxford: Clarendon Press.

Dickens, F. \& Williamson, D. H. (1958). Formaldehyde as an acceptor aldehyde for transketolase, and the biosynthesis of triose. Nature, London 161, 1790.

Gancedo, C., Gancedo, J. M. \& Sols, A. (1968). Glycerol metabolism in yeasts. Pathways of utilization and production. European Journal of Biochemistry 5, 165-172.

de la Haba, G., Leder, I. G. \& Racker, E. (1955). Crystalline transketolase from bakers' yeast: isolation and properties. Journal of Biological Chemistry 214, 409-426.

Hers, H. G. (1962). Triokinase. Methods in Enzym$\operatorname{ology} 5,362$.

Kato, N., Nishizawa, T., Sakazawa, C., Tani, Y. \& Yamada, H. (1979). Xylulose 5-phosphate dependent fixation of formaldehyde in a methanolutilizing yeast Kloeckera sp. no. 2201. Agricultural and Biological Chemistry 43, 2013-2015.
Lindley, N. D., Waites, M. J. \& Quayle, J. R. (1980). A modified pulse labelling technique for the detection of early intermediates in microbial metabolism: detection of $\left[{ }^{14} \mathrm{C}\right]$ dihydroxyacetone during assimilation of $\left[{ }^{14} \mathrm{C}\right]$ methanol by Hansenula polymorpha. FEMS Microbiology Letters 8, 13-16.

O'ConnoR, M. \& QuAYLE, J. R. (1979). Mutants of Hansenula polymorpha and Candida boidinii impaired in their ability to grow on methanol. Journal of General Microbiology 113, 203-208.

van DiJKen, J. P., OtTo, R. \& HARDER, W. (1976). Growth of Hansenula polymorpha in a methanollimited chemostat. Physiological responses due to the involvement of methanol oxidase as a key enzyme in methanol metabolism. Archives of Microbiology 111, 137-144.

van Dijken, J. P., Harder, W., Beardsmore, A. J. \& QuAYLE, J. R. (1978). Dihydroxyacetone: an intermediate in the assimilation of methanol by yeasts? FEMS Microbiology Letters 4, 97-102.

WaITES, M. J. \& QuAYle, J. R. (1980). Dihydroxyacetone: a product of xylulose 5-phosphatedependent fixation of formaldehyde by methanolgrown Candida boidinii. Journal of General Microbiology 118, 321-327. 